\title{
DEGRADATION OF VERMILION RED COLOR IN OIL AND MURAL PAINTINGS: A COMPARATIVE APPLIED STUDY
}

\author{
Abo-Taleb, Th. \& Orabi, E. ${ }^{(*)}$ \\ Conservation dept., Faculty of Archaeology, Aswan Univ., Aswan, Egypt \\ E-mail:ezz_arabi@yahoo.com
}

\begin{abstract}
The present study investigates and compares the vermilion red color change phenomenon in an oil painting executed on wood from the $18^{\text {th }}$ century stored at the Archaeological Museum Store of Manial Palace Museum, Cairo and a mural painting executed using Tempera from the Greco-Roman Period in a destroyed archeological house next to Medinet Madi Temple, (35kms far from Fayoum city). The vermillion red color may change to dark red, brown, or grayish-white due to the exposure to the environmental conditions and pollutants, the common role of both light and chlorine as the main factors of red discoloration, some impurities in color components, as well as the dissolved salts and organic media used in painting. The blackness of the color was detected after doing an analytical study to identify the damaged products of the vermillion red using different methods of analysis (i.e. microscopy, X-ray diffraction, Energy Dispersive $X$-rays and Infrared). The change to gray color in oil paintings due to the presence of the prokovite was associated with cinnabar. In the mural painting, it resulted from the conversion to black hypercinnabar, not to the resin.
\end{abstract}

Keywords: Cinnabar, Meta cinnabar, Hypercinnabar, Vermillion, Effect of light, Chlorine, Humidity

\section{Introduction}

The first use of red vermillion- known as cinnabar- dates back to the New Stone Age 3000 B.C. in funeral objects. Then, it was used by ancient Greeks between the third and fourth centuries BC. It has become scarcer since the mid-first century $\mathrm{AD}$ [1]. Vermillion was used in classic mural paintings in Bombay, in the mural paintings of the Gothic Church in the Monastery of Pedralbes in 1326 AD in Spain, and Love of the Mag oil painting by Robbins (1577-1640 AD) at the Royal Museum of Fine Arts in Antwerp [2]. Vermillion red color deteriorates and changes slowly and irreversibly, affecting the cultural heritage in both museums and archeological sites due to exposure to light, impurities, relative humidity, inorganic pollutants, chlorine, and faulty restoration using inappropriate materials and/or methods [3]. These factors often cooperate to make a change to the red color of the crystalline form by oxidation and its transformation into the black metacinnabar of the crystalline form of cubic, which changes the appearance of the artwork. It is difficult to distinguish between $\mathrm{HgS}-\alpha$ and $\beta-\mathrm{HgS}$ by chemical analyzes because they often identify sulfur and mercury only [4]. Thus, researchers conducted various studies to find out the basic process of decomposition. It was done using X-ray and electrochemical 
analysis. It has developed many hypotheses, e.g. chlorine can be a catalyst [5] for the degradation of color by light. Therefore, $\alpha-\mathrm{HgS}$ turns into mineral mercury and sulfur [6]. The cause of the red color change can be effectively explained in two separated stages. First, chlorine acts as a catalyst during the lightinduced conversion of mercury sulfide $\mathrm{HgS}$ (photo-oxidation) to $\mathrm{Hg}(0)$ and $\mathrm{S}$ (0) [7]. Then, mercury reacts with chlorine to form different mercury chlorine compounds. Light-sensitive $\alpha-\mathrm{Hg}_{3} \mathrm{~S}_{2} \mathrm{Cl}_{2}$ compounds can be converted to $\mathrm{Hg}_{2} \mathrm{Cl}_{2}$ after the loss of the crystalline network through oxidation and volatilization [8], leaving the underlying mercury [9]. Mineral mercury may cause $\mathrm{Hg}_{2} \mathrm{Cl}_{2}$ to become a gray $\mathrm{HgCl}_{2}$ because of chlorine gas $\mathrm{ClO}$, which has been demonstrated through microscopic studies of historical panels' samples with a high concentration of chloride in areas adjunct to some degraded areas [10]. It also explains the red color resulting from increasing light, which causes automatic mercury deposition on the surface because the optical energy is converted to light energy. When the color absorbs light energy, electrons are excluded. They move from lower-energy orbits to higher orbits. By continuing this process, they gain their own colors [11]. Light sensitivity electrons due to the red vermillion transformations can cause color changes because photosynthesis electrons have enough power to reduce $\mathrm{Hg}^{2}$ to $\mathrm{Hg}$. They may return to the basic state after losing energy, causing color changes because chlorine is a catalyst for the collection, analysis, display, and chemical oxidation interaction, which turns $\mathrm{Hg}$ (II) $\mathrm{S}$ to $\mathrm{Hg}$ and S. After that, $\mathrm{Cl}$ interacts with $\mathrm{Hg}$ to give $\mathrm{HgCl}_{2}$ and $\mathrm{HgS}$ for corderoite $(\alpha$ $\mathrm{Hg}_{3} \mathrm{~S}_{2} \mathrm{Cl}_{2}$ ) formation $\left(\mathrm{Hg}_{3} \mathrm{~S}_{2} \mathrm{Cl}_{2}\right)$ that turns into calomel [12]. Exposure to light continues the changes of $\mathrm{Hg}_{2} \mathrm{Cl}_{2}$ to mercury chloride $\left(\mathrm{HgCl}_{2}\right)$ and mineral mercury (Hg) [13]. The interaction mechanism continues in the light until the color degradation occurs completely. Damage depends on the presence of air pollutants [14]. After exposure to the light, chlorine is a catalyst for chemical photo oxidant reaction [15], the $\alpha$ - Cinnabar changes to mineral mercury and sulfur, then chlorine ion interacts with the mineral mercury and the mercury chloride, and the ion chlorine interacts with cinnabar to give sulfur (S) and corderoite $\left(\mathrm{Hg}_{3} \mathrm{~S}_{2} \mathrm{Cl}_{2}\right)$ that is converted to calomel. It is a lightsensitive compound that turns into mercury chloride and mineral mercury. Dark black also may occur because of the presence of other ions, such as potassium, zinc [16], iron sulfide and selenium [17], or other impurities in contact with $\mathrm{HgS}$, which greatly affects the mineral nature and turns the color dark. X-ray diffraction was used to identify the damaged products on the red color surface, and UV spectroscopy was employed to determine the color and its type. The interaction is performed according to the following equations.

$$
\begin{aligned}
& \text { 1. } \alpha-\mathrm{HgS} \stackrel{\mathrm{cl}}{\longrightarrow} \mathrm{Hg}(0)+\mathrm{S}(0) \\
& \text { 2. } \mathrm{Hg}(0)+2 \mathrm{Cl}^{-1} \longrightarrow \mathrm{HgCl}_{2} \\
& \text { 3. } \alpha-3 \mathrm{HgS}+2 \mathrm{Cl}^{-1} \longrightarrow \mathrm{S}(0)+\mathrm{Hg}_{3} \mathrm{~S}_{2} \mathrm{Cl}_{2} \\
& \text { 4. } \mathrm{Hg}_{3} \mathrm{~S}_{2} \mathrm{Cl}_{2} \longrightarrow \mathrm{Hg}+2 \mathrm{~S}+\mathrm{Hg}_{2} \mathrm{Cl}_{2} \\
& \text { 5. } \mathrm{Hg}_{2} \mathrm{Cl}_{2} \longrightarrow \mathrm{Hg}+\mathrm{HgCl}_{2}
\end{aligned}
$$

This study aims to explain the reasons for the most signifi-cant deterioration factors of color change to avoid red color deterioration in the future and to choose appropriate treatment materials. 


\section{Materials and Methods}

\subsection{Study objects}

The study was carried out on two paintings. One of them is an oil painting dating back to the late $18^{\text {th }}$ cen-tury entitled "flower bouquet on oval wood" and stored in the archaeological museum store of Manial Palace Museum that lies on the main street with pollutants from transportation. The other is a mural painting executed in the tempera technique dating back to the Greco-Roman period in a destroyed archeological house next

to Medinet Madi temple. Its decorative units include geometric elements of triangles, as well as horizontal and vertical lines. The house was built with bricks coated with mud plaster, whitewash made from lime, then a layer of red and orange colors. In the present case studies, red changed to gray, black, and white areas in oil painting, fig. (1-a). On the contrary, it changed to gray and black in the mural painting, fig. (1-b).

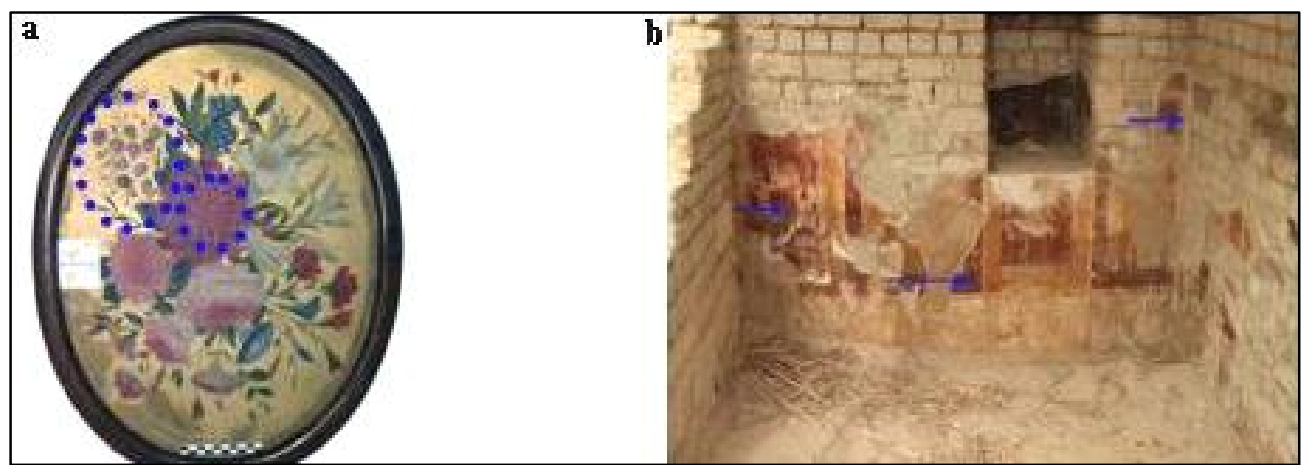

Figure (1) Shows $\underline{\mathbf{a}}$. a bouquet of flowers with the red color that changed to gray and white, $\underline{\mathbf{b}}$. a Roman-era mural painting with a red color that changed to gray and black

\subsection{Methods of investigation}

The study materials were examined by oblique light, scanning electron microscopy and Olympus (DP 731) connected to a computer unit with a camera (100x magnification), X-ray diffraction, Energy Dispersive X-rays, and infrared spectroscopy (FTIR). Analyses were performed to identify the type of painting, ground co- mponent, and medium. UV/VIS spectrophotometer analysis was utilized for color determination and concentration estimation. It could produce comparable spectra of the analyzed samples in the spectral range of $360-1000 \mathrm{~nm}$. Then, the colored materials could be identified.

\section{Results}

\subsection{Results of the visual inspection and stereo microscopic examination}

The visual inspection method is the first stage of screening using some lenses that magnify up to $6 x$. The visual inspection of the oil painting showed some color changes. Most of the surface had accumulations of dust clots and some crystallized salts, as shown in fig. (2-a). The mural painting had some crystallized salts inside the cracks and a weak and fragile surface. It was very easily fragmented because of its weak mineral composition and the breakdown of its component grains, and color changed in some places, fig. (2-b). Stereo microscope examination of the oil painting showed the color change of red to dark brown, dark gray, and white with a slight bluishgray, as shown in fig. $(3-a, b)$. In the case of the mural painting, stereo microscope examination showed some changes in the red color to a dark color closer to black with gray spots in some areas and heterogeneous points of dark gray that distorted the archeological surface as shown in (3-c,d). 

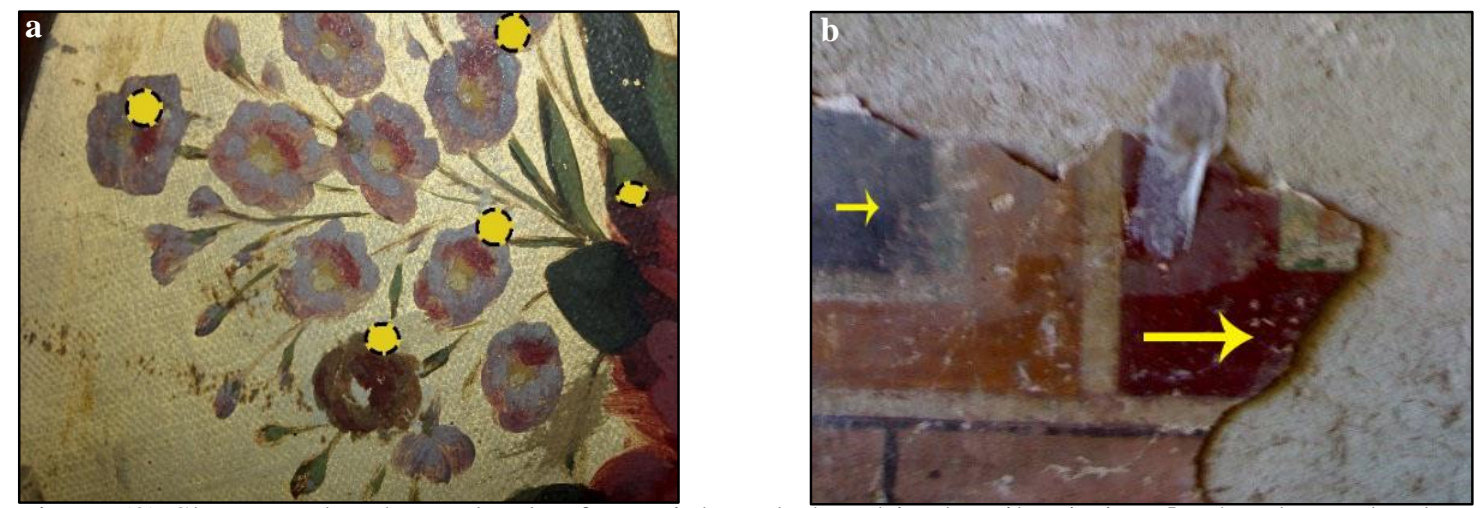

Figure (2) Shows a. the changed color from pink to dark red in the oil painting, $\underline{\mathbf{b}}$. the changed color from pink to dark red and from dark pink to dark gray in the mural painting
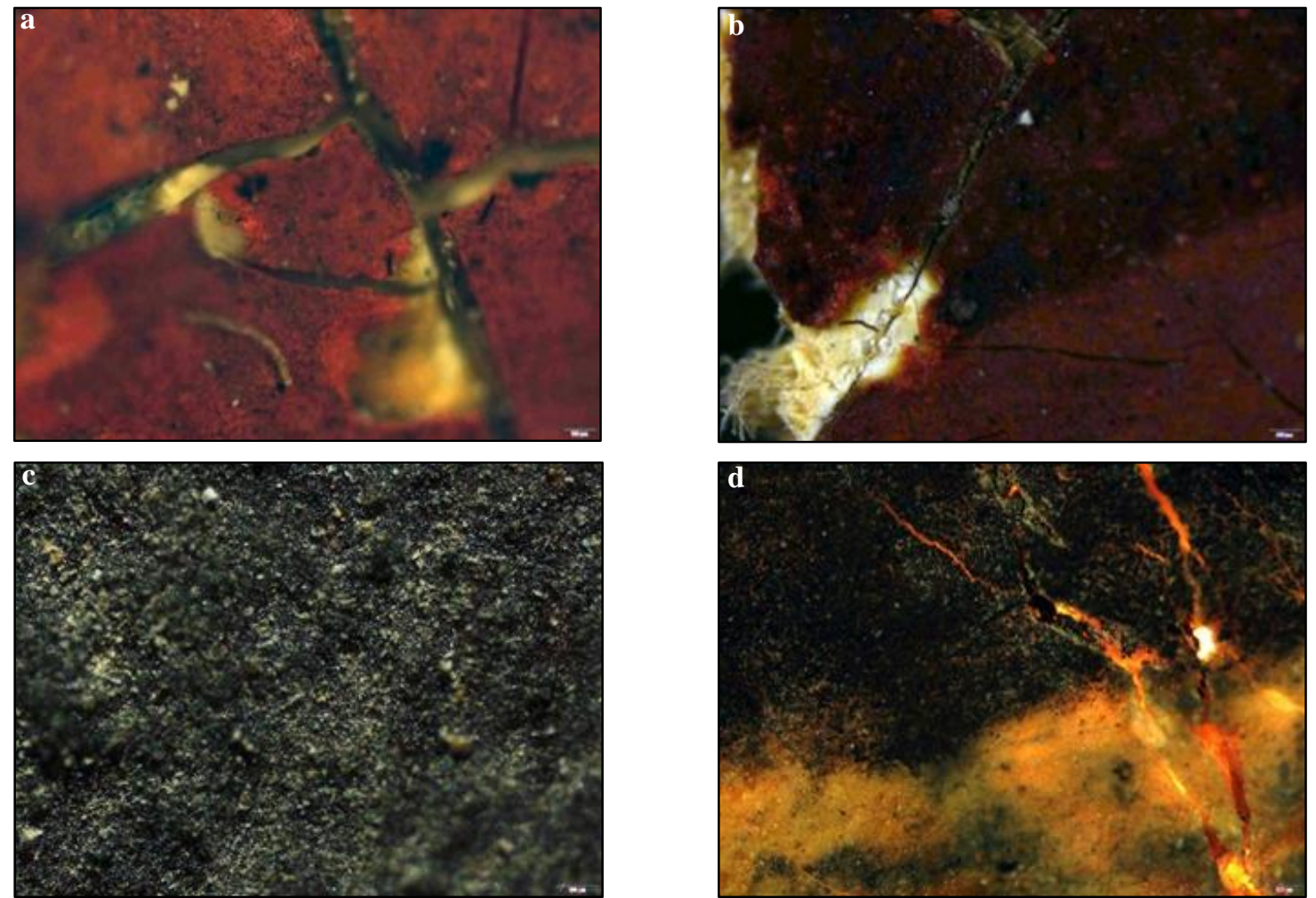

Figure (3) Shows stereo microscopic examination $\underline{\mathbf{a}}$. red color, $\underline{\mathbf{b}}$. accompanied by the meta-cinnabar in (the oil painting), $\underline{\mathbf{c}}$. black areas of metacinnabar, $\underline{\mathbf{d}}$. chlorine compounds in (the mural painting)

\subsection{Results of SEM investigation and EDX examination}

SEM-EDX analyses show a black layer over the red color (mercury sulfide) topped by a dark thin layer in light gray, as well as a deterioration of the oil paintings, fig. (4-a,b). On the contrary, the mural painting shows a thicker black decomposition layer on the surface of the red color with a gray degradation layer and deterioration, fig. (4-c,d). EDX analysis of the oil painting, tab. (1-a) and fig. (5$a, b)$ shows the composition and the colored elemental distribution map. On the other hand, tab. (1-b) and fig. (6-a,b) shows the composition and the colored elemental distribution map of mural painting sample.

Table (1) EDX shows the percentages of the elements for both mural painting and oil paintings

\begin{tabular}{|c|c|c|c|c|c|c|c|c|c|c|c|c|c|c|}
\hline \multirow[t]{2}{*}{ Samples } & \multicolumn{14}{|c|}{ Elemental Ratios \% } \\
\hline & $C$ & $\boldsymbol{O}$ & $A l$ & Si & $S$ & $C l$ & $\boldsymbol{K}$ & Ca & $F e$ & $Z n$ & $B a$ & $H g$ & $P b$ & Se \\
\hline & 30.95 & 35.76 & 2.99 & 3.59 & 3.10 & 2.11 & 1.09 & 2.60 & 3.53 & 1.47 & 1.79 & 7.00 & 2.02 & 0.01 \\
\hline Wall Paint & 39.5 & 25.51 & 2.48 & 1.83 & 6.10 & 3.3 & 1.05 & 3.54 & 2.39 & 1.73 & 2.17 & 8.04 & 4.00 & - \\
\hline
\end{tabular}



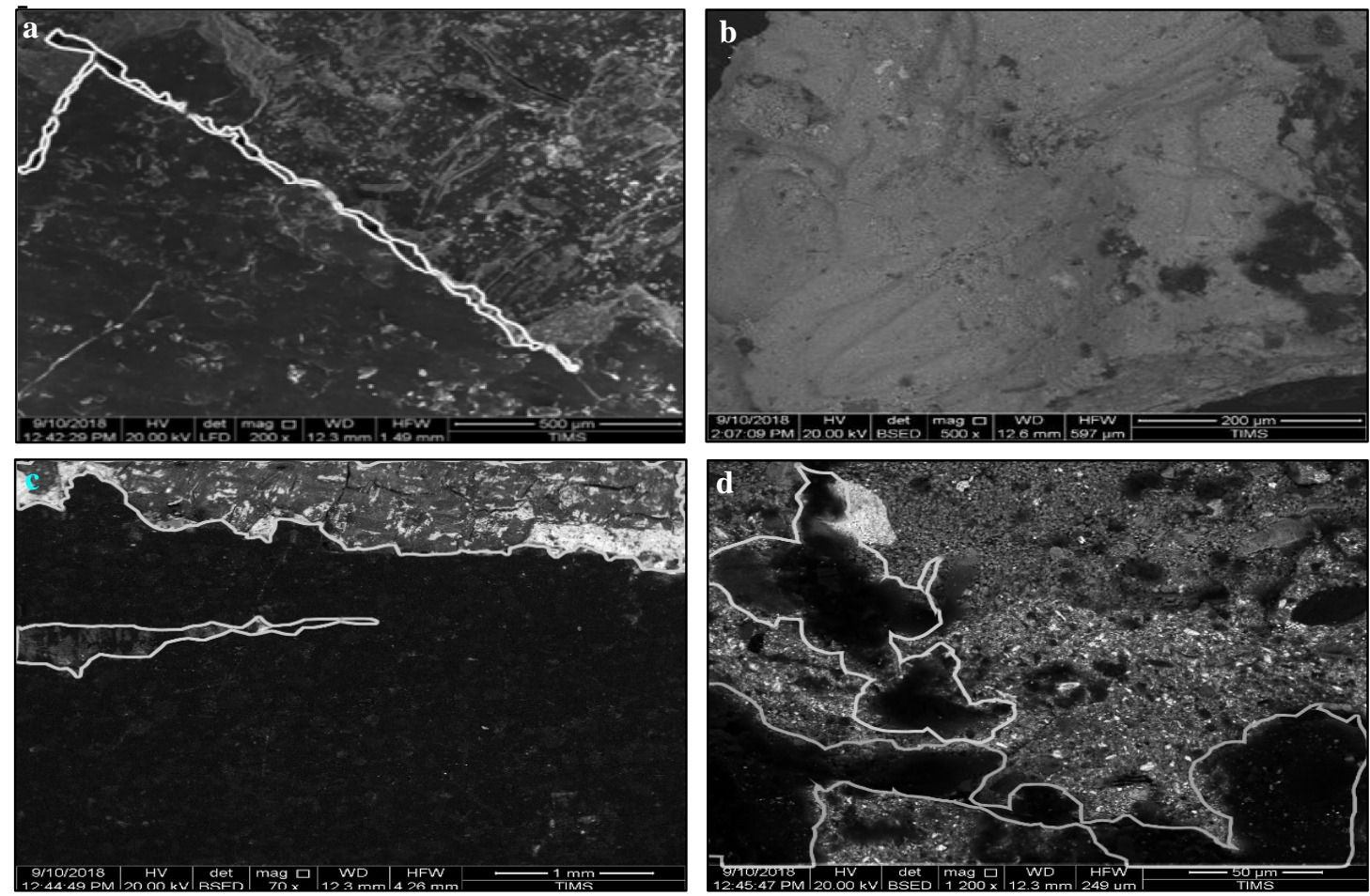

Figure (4) Shows SEM micrographs $\underline{\mathbf{a}}$. thin black areas of meta-cinnabar, $\underline{\mathbf{b}}$. white areas of calomel (in the

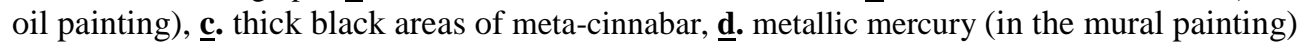
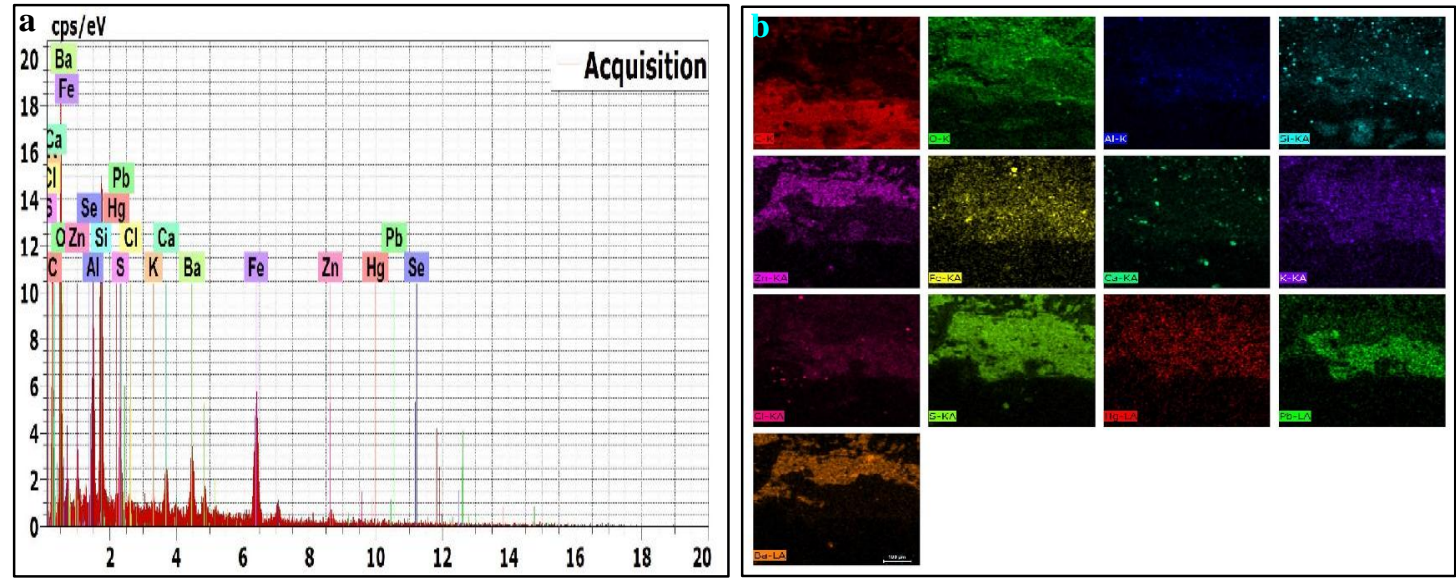

Figure (5) Shows $\underline{\text { a. }}$ EDX analysis chart of the red color sample, $\underline{\mathbf{b}}$. a colored elemental distribution map of the red color sample in oil painting
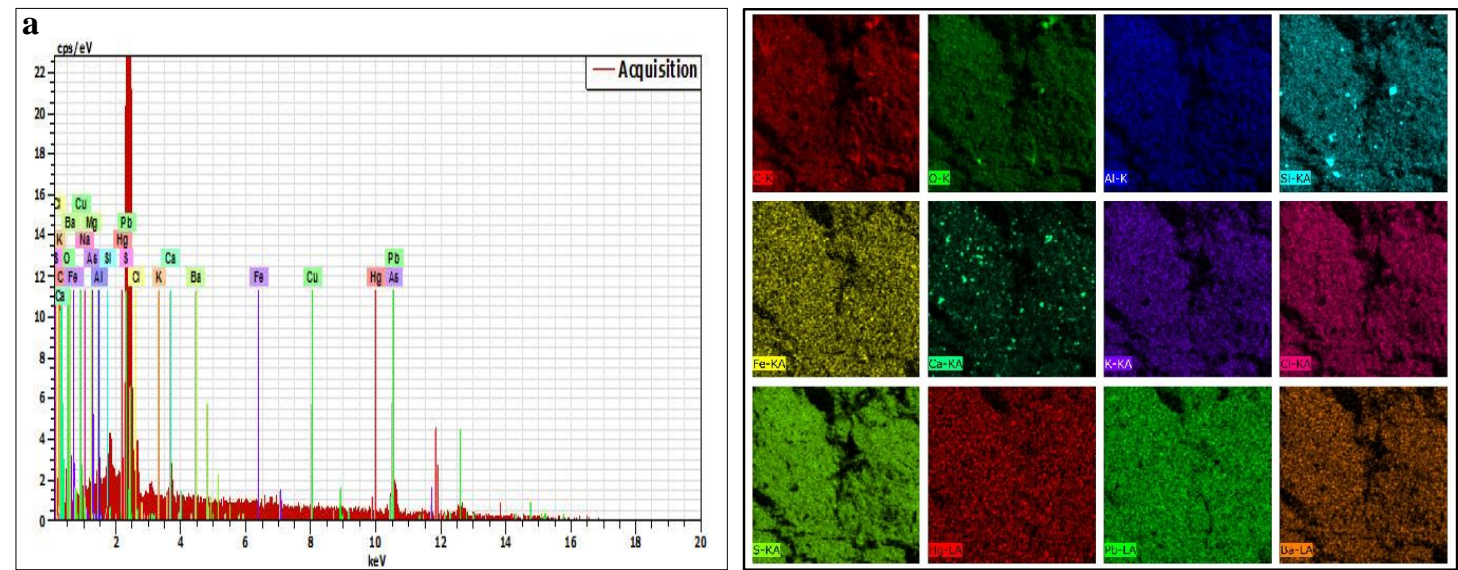

Figure (6) Shows $\underline{\mathbf{a}}$. EDX analysis chart of the red color sample, $\underline{\mathbf{b}}$. a colored elemental distribution map of the red color sample in mural painting 


\section{3. $X R D$ examination results}

The X-ray diffraction (XRD) analysis of a sample from the degraded oil pai-nting, fig (7-a) shows calcite $\left[\mathrm{CaCO}_{3}\right](19.4 \%)$ (card 1808-88) referring to the ground layer [18], Poyarkovite $\left[\left(\mathrm{Hg}_{2}{ }^{+2}\right)_{3} \mathrm{Cl}_{2} \mathrm{O}_{2}\right]$ $(56.67 \%)$ associated with vermilion (card 0920-033), goethite $\left[\mathrm{FeO}(\mathrm{OH}) \cdot \mathrm{H}_{2} \mathrm{O}\right]$ (22.0\%) (card 464-81) used under the painting, and calcite. The XRD results of the mural painting, fig (7-b) show hypercinnabar $[\gamma$-Hgs] $(20.2 \%)$ (card 079819), which is the third form of mercury sulfide and its color is black [19], imandrite $\left[\mathrm{Na}_{12}, \mathrm{Ca}_{3}, \mathrm{Fe}_{2}\left(\mathrm{Si}_{6} \mathrm{O}_{18}\right)_{2}\right](26.17 \%)$ (card 84-0037), paulmooreite $\left[\mathrm{Pb}_{2} \mathrm{As}_{2} \mathrm{O}_{5}\right]$ (7.2\%) (card 1364-83), and arsenic sulfide $\left(\mathrm{AS}_{4} \mathrm{O}_{5}\right)(16.4 \%)$ (card 0694-72).
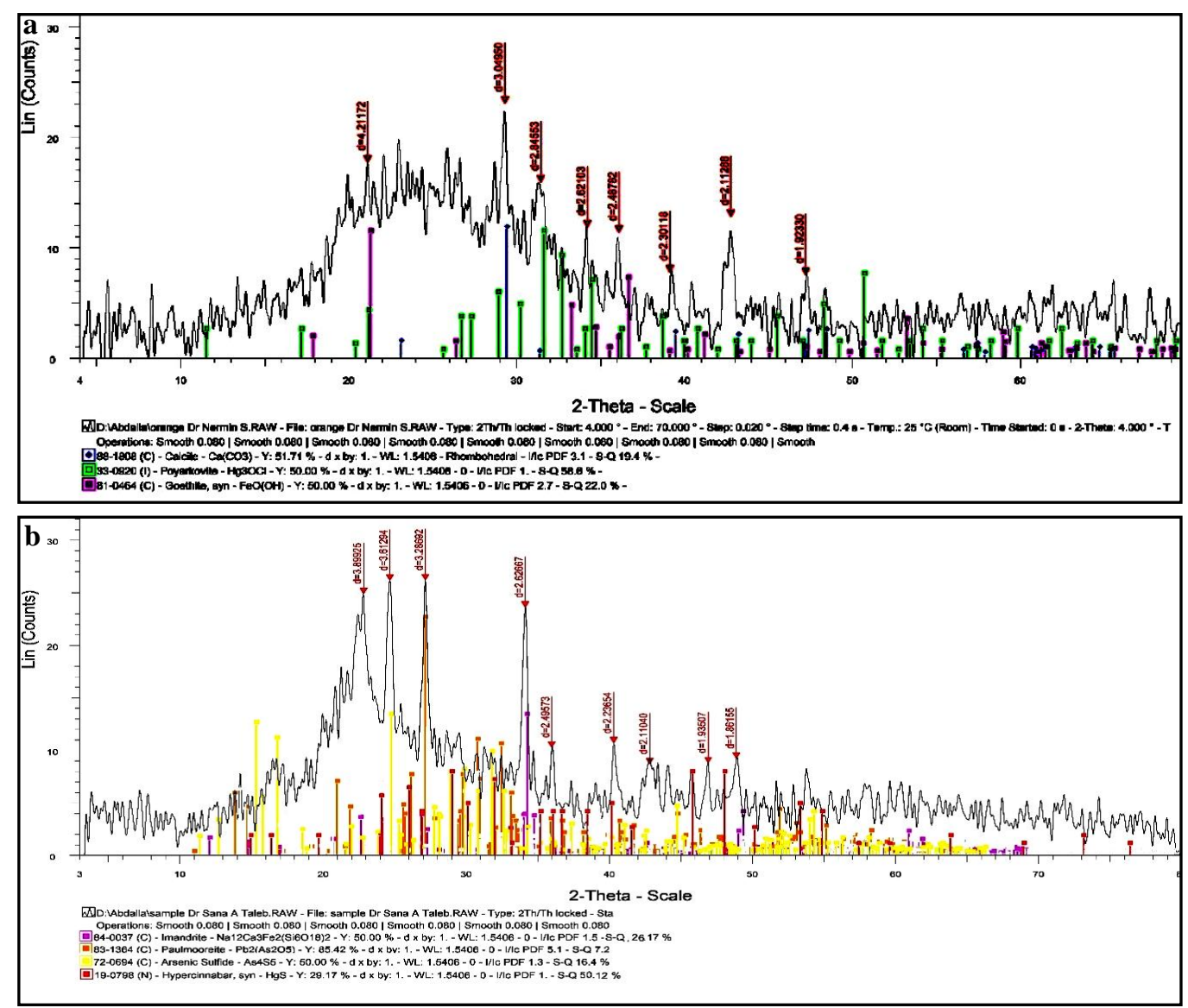

Figure (7) Shows XRD pattern of red color $\underline{\mathbf{a}}$. oil painting sample, $\underline{\mathbf{b}}$. mural painting sample

\subsection{FTIR examination results}

The analysis of the infrared spectroscopy (FTIR) was done to determine the natural organic binder and the ground layer by identifying the active groups [20]. The oil painting sample's analysis, fig (8-a) shows that the binder is linseed oil due to the absorption bands at a wavelength of $\left(3402.3 \mathrm{~cm}^{-1}\right)$. The wavelength $\left(3543 \mathrm{~cm}^{-1}\right)$ is indicated by the $\mathrm{O}-\mathrm{H}$ stretching band group. The absorption bands at the wavelength $\left(2924.6 \mathrm{~cm}^{-1}\right)$ and the wavelength $\left(2853.61 \mathrm{~cm}^{-1}\right)$ are indicated by the $\mathrm{C}-\mathrm{H}$ group, which is a stretching band group. The wavelength in the range $\left(1745.4 \mathrm{~cm}^{-1}\right)$ is indicated by the $\mathrm{C}=\mathrm{O}$ group stretching band group, and the wavelength in the range (1456. $595 \mathrm{~cm}^{-1}$ ) is indicated the $\mathrm{C}-\mathrm{H}$ group bending bands group. The wavelength in the range $\left(1139.383 \mathrm{~cm}^{-1}\right)$ is indicated by the C-O stretching bands' group. The wavelength in the range $\left(873.002 \mathrm{~cm}^{-1}\right)$ indicated calcite. The presence of the absorption bands in the range (1139.38 $\mathrm{cm}^{-1}$ ) is indicated by the asymmetric group $\left(\mathrm{SO}_{4}\right)$ stretching band group and the wavelengths in the range (3643.210 $\left.\mathrm{cm}^{-1}\right)$. The wavelength $\left(3542.986 \mathrm{~cm}^{-1}\right)$ 
is indicated by the $\mathrm{O}-\mathrm{H}$ stretching bands group, referring to calcium sulfate salts. In addition, the wavelengths in the ranges $\left(1465.6 \mathrm{~cm}^{-1}\right),\left(1621.6 \mathrm{~cm}^{-1}\right),(2853.5$ $\left.\mathrm{cm}^{-1}\right)$ and $\left(2922.5 \mathrm{~cm}^{-1}\right)$ indicated animal glue. The analysis of the mural painting sample, fig (8-b), shows that the binder is egg yolk from the absorption bands at the wavelength in the range of (199. $\left.3429 \mathrm{~cm}^{-1}\right)$ indicated by the $(\mathrm{OH})$ hydroxyl group. The wavelength in the range $\left(2922.330 \mathrm{~cm}^{-1}\right)$ and $(2852.350$ $\left.\mathrm{cm}^{-1}\right)$ are indicated by the $(\mathrm{C}-\mathrm{H})$ group of fatty acids. The wavelength in the range $\left(1743.340 \mathrm{~cm}^{-1}\right)$ is indicated by the presence of the $\mathrm{C}=\mathrm{O}$ esters group. The wavelength in the range (1554.293 $\mathrm{cm}^{-1}$ ) is indicated by the (amide 11) group and absorption bands at a wavelength in the range $\left(1635 \mathrm{~cm}^{-1}\right)$ indicating the (amid1) group. The wavelength in the range $\left(1456.595 \mathrm{~cm}^{-1}\right)$ is indicated by the $(\mathrm{C}-\mathrm{H})$ group, suggesting the presence of a protein because of using egg yolks as a medium. The absorption bands at wavelengths in the range $(874.222$ $\left.\mathrm{cm}^{-1}\right),\left(712.730 \mathrm{~cm}^{-1}\right),\left(2513.070 \mathrm{~cm}^{-1}\right)$, and $\left(1458.630 \mathrm{~cm}^{-1}\right)$ are indicated by calcite. The damaged products form a white layer on the surface in the sample show the absorption bands at wavelengths in the range $\left(3542.986 \mathrm{~cm}^{-1}\right),(3402.322$ $\left.\mathrm{cm}^{-1}\right),\left(1652.219 \mathrm{~cm}^{-1}\right)$ indicated by the $\mathrm{S}-\mathrm{O}$ groups. The wavelength in the range $\left(1635.021 \mathrm{~cm}^{-1}\right)$ and $\left(1652.219 \mathrm{~cm}^{-1}\right)$ are indicated by the $\mathrm{HOH}$ group of water molecules, and the strong absorption bands at wavelengths in the range (1074.613 $\mathrm{cm}^{-1}$ ) indicated the $\mathrm{Si}-\mathrm{O}$ stretching of silicates group. The absorption bands at the wavelength in the range $(910.220$ $\mathrm{cm}-1)$ are indicated by the (Si-O-Al) clay group. The wavelengths in the range $\left(1465 \mathrm{~cm}^{-1}\right),\left(1621.5 \mathrm{~cm}^{-1}\right),\left(2853.5 \mathrm{~cm}^{-1}\right)$, and $\left(2922.5 \mathrm{~cm}^{-1}\right)$ indicated animal glue as adhesive in the ground layer. The analysis of UV/VIS spectrophotometer (UV), fig (8-c) identified and compared spectra with the red color spectral database characterized by the slope with sharp [21] inclination at $600 \mathrm{~nm}$ and $620 \mathrm{~nm}$ [22]. It was found that the sample of oil paintings achieved a higher wavelength at a sharp inflection point at $0.675 \mathrm{~nm}$, the sample of the mural painting had a sharp inflection point at $0.632 \mathrm{~nm}$.
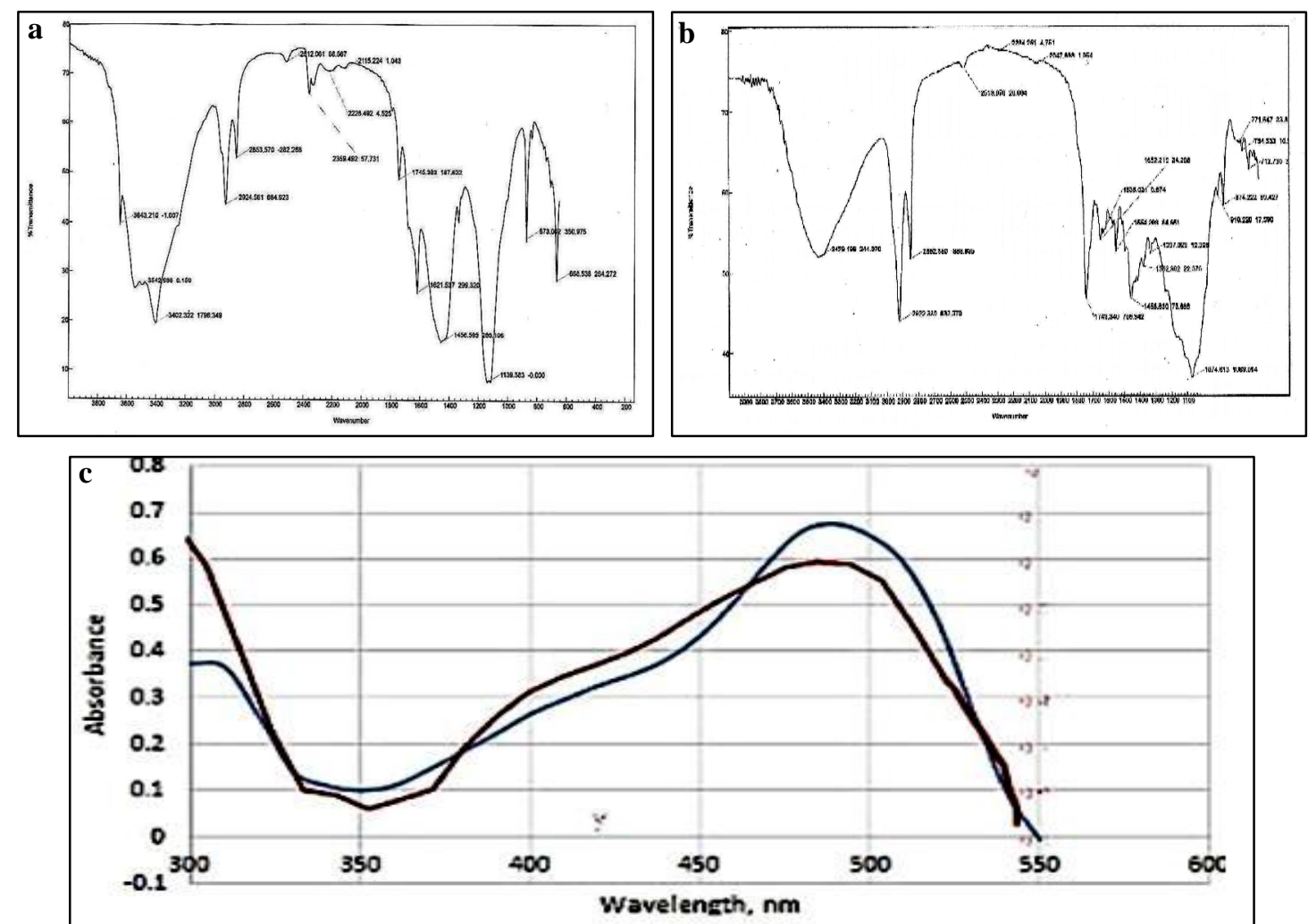

Figure (8) Shows transmission infrared spectra of red sample $\underline{\mathbf{a}}$. in the oil painting, $\underline{\mathbf{b}}$. in mural painting sample, $\underline{\mathbf{c}}$. ultraviolet spectroscopy chart of the oil painting (blue) and the mural painting (red) 


\section{Discussion}

The cinnabar color change occurs in the presence of light [23] natural or artificial and chlorine ions, which may be produced from the cleaning materials used for the sterilization of floors in museums, included in works of art such as varnishes, adhesives that contain protein [24], atmosphere, air pollutants, or acid rain. Analysis of the samples using $\mathrm{x}$-ray diffraction showed some compounds, such as divalent pyruquite $\left(\left(\mathrm{Hg}^{+2}{ }_{2}\right)_{3} \mathrm{Cl}_{2} \mathrm{O}_{2}\right)$ and hyper cinnabar trivalent black $\left(\mathrm{Y}-\mathrm{Hg}_{3}\right.$ $\mathrm{S}_{2} \mathrm{Cl}_{2}$ ), as well as some impurities including clay minerals [25] such as Imandrite $\left(\mathrm{Na}_{12}\right.$ $\mathrm{Ca}_{3} \mathrm{Fe}_{2}\left(\mathrm{Si}_{6} \mathrm{O}_{18}\right)$. The colors of the mercury compounds vary depending on their chemical composition. The presence of goethite $\left[\mathrm{FeO}(\mathrm{OH}) \cdot \mathrm{H}_{2} \mathrm{O}\right]$ with red cinnabar is due to the various impurities associated with the color, which vary according to the color source [26]. Calcite back appears in the painting ground or with the cinnabar. Gypsum is not specified by XRD because its amount may be below the detection limit (usually 3 to $5 \%$ by weight). The SEM-EDX and FTIR analyses demonstrated the presence of gypsum dihydrate $\left(\mathrm{CaSO}_{4} .2 \mathrm{H}_{2} \mathrm{O}\right)$ on the surface. The XRD analysis of the mural painting showed paulmoorite, $\mathrm{Pb}_{2}\left(\mathrm{As}_{2} \mathrm{O}_{5}\right)$ arsenic sulfide [27], explaining the blackening of the red cinnabar. The EDX analysis showed that the red color sample of both the oil and mural painting plates composed of mercury, chlorine, and sulfur, indicating the change of red cinnabar. Chlorine is higher than sulfur in the oil painting. Thus, some areas appear white. On the contrary, in the mural painting, sulfur is higher than chlorine. Therefore, some areas appear black, suggesting that the external deterioration sources, e.g. light, and the concentration of chlorine and sulfur play a major role in the degradation of $\alpha-\mathrm{HgS}$ [28]. Other elements are involved in the damage, such as iron, silica, potassium, and calcium. The microscopic examination showed a darker layer of black dissolution in the mural painting. It is thicker on the deteriorated surface compared to the oil paintings because the mural painting is exposed to direct sunlight, air pollutants, and acid rain because the archaeological area was destroyed and left only ruins and the wall carrying this mural painting. The microscopic examination showed also other ions, e.g. calcium, abundant in the painting ground. They increased calcium and sulfur on the surface, indicating gypsum $\left(\mathrm{CaSO}_{4}\right.$. $2 \mathrm{H}_{2} \mathrm{O}$ ) [29]. The presence of calcium, oxygen, and carbon in both samples indicates calcium carbonate. The FTIR examination indicated the presence of gypsum in both oil and mural painting, as well as clay minerals [30] affecting color change. Furthermore, the UV examination indicated the presence of Vermilion in both oil and mural paintings.

\section{Conclusion}

The XRD and spectral analyses demonstrate the movement of the degradation of mercury sulfide under the influence of sunlight or museum lamps and chlorine. The color change results from the decomposition of cinnabar to corderoite and turns it into calomel deposited on the outer part of the colored surfaces. Because of its solubility in water, it is more mobile in the cycles of moisture. Thus, it can dissolve the calomel (partially) and the result of the unstable corderoite which changes again to calomel.

\section{Reference}

[1] Ballirano, P., Botticelli, M. \& Maras, A. (2013). Thermal behavior of cinnabar, $\alpha-\mathrm{HgS}$, and the kinetics of the $\beta$-HgS (metacinnabar) $\rightarrow \alpha-\mathrm{HgS}$ conversion at room temperature, European J. of Mineralogy, Vol. 25 (6), pp: 957-965.
[2] Foord, E., Berendsen, P. \& Storey, L., (1974). Corderoite, first natural occurrence of $\alpha-\mathrm{Hg}_{3} \mathrm{~S}_{2} \mathrm{CI}_{2}$, from the Cordero mercury deposit, Humboldt County, Nevada, J. of Earth and Planetary Materials, Vol. 59 (7-8), pp: 652-655. 
[3] Rytuba, J., (2003). Mercury from mineral deposits and potential environmental impact, Environmental Geology, Vol. 43 (3), pp: 326-338

[4] Noller, R., (2015). Cinnabar reviewed: Characterization of the red pigment and its reactions, Studies in Conservation, Vol.60 (2), pp: 79-87.

[5] Spring, M. \& Grout, R. (2002). The blackening of vermilion: An analytical study of the process in paintings, National Gallery Technical Bulletin, Vol. 23, pp: 50-61.

[6] Neiman, M., Balonis, M. \& Kakoulli, I., (2015). Cinnabar alteration in archaeological wall paintings: An experimental and theoretical approach, Applied Physics A, Vol. 121 (3), pp: 915-938.

[7] McCormack, J., (2000). The darkening of cinnabar in sunlight, Mineralium Deposita, Vol.35 (8), pp: 796-798.

[8] Keune, K. \& Boon, J., (2005). Anaytical imaging studies clarifying the process of the darkening of vermilion in paintings, Analytical Chemistry, Vol.77 (15), pp: 4742-4750.

[9] Cesareo, R., Frazzoli, F., Mancini, C., Sciuti, S., Marabelli, M., Mora, P., Rotonda, P. \& Urbani, G., (1972). Nondestructive analysis of chemical elements in paintings and enamels, Archaeometry, Vol. 14 (1), pp: 65-78

[10] Béarat, H., (1996). Chemical and mineralogical analyses of Gallo-Roman wall painting from Dietikon, Switzerland, Archaeometry, Vol. 38 (1), pp: 81-95

[11] Anaf, W., Janssens, K. \& De Wael, K., (2013). Formation of metallic mercury during photodegradation/photodarkening of $\alpha-\mathrm{HgS}$ : Electrochemical evidence, Angewandte Chemie, Vol. 125 (48), pp: 12568-12571.

[12] Porck, H. (2000). Rate of paper degradation: The predictive value of artificial aging tests, European Commission on Preservation and Access. Amsterdam, 40 p.

[13] Hogan, C. \& Da Pieve, F., (2015). Colour degradation of artworks:
An ab initio approach to X-ray, electronic and optical spectroscopy analyses of vermilion photo darkening, J. of Analytical Atomic Spectrometry, Vol. 30 (3), pp: 588-598.

[14] Ballirano, P., Botticelli, M. \& Maras, A. (2013). Thermal behaviour of cinnabar, $\alpha-\mathrm{HgS}$, and the kinetics of the $\beta-\mathrm{HgS}$ (metacinnabar) $\rightarrow \alpha-\mathrm{HgS}$ conversion at room temperature, European J. of Mineralogy, Vol. 25 (6), pp: 957-965.

[15] Patel, B., Rath, S., Sarangi, S., \& Sahu, S., (2007). HgS nanoparticles: structure and optical properties, Applied Physics A, Vol. 86 (4), pp: 447-450.

[16] Kim, C., Bloom, N., Rytuba, J., \& Brown, G., (2003). Mercury speciation by X-ray absorption fine structure spectroscopy and sequential chemical extractions: A comparison of speciation methods, Environmental Science \& Technology, Vol. 37 (22), pp: 5102-5108.

[17] Potter, R. \& Barnes, H., (1978). Phase relations in the binary $\mathrm{Hg}$ S, American Mineralogist, Vol. 63 (11-12), pp: 1143-1152.

[18] Noble, P., Boon, J. \& Wadum, J., (2002). Dissolution, aggregation and protrusion. Lead soap formation in $17^{\text {th }}$ century grounds and paint layers, in: Hermens, E. (ed.) Art Matters, Netherlands technical studies in art, The Netherlands, pp: 46-61

[19] Clarke, M. (2001). The analysis of medieval European manuscripts, Studies in Conservation, Vol. 46 (2), pp: 3-17.

[20] Clark, R. \& Cobbold, D., (1978). Characterization of sulfur radical anions in solutions of alkali polysulfides in dimethylformamide and hexamethylphosphoramide and in the solid state in ultramarine blue, green, and red, Inorganic Chemistry, Vol. 17 (11), pp: 3169-3174.

[21] Radepont, M., de Nolf, W., Janssens, K., Van der Snickt, G., Coquinot, Y., Klaassen, L. \& Cotte, 
M., (2011). The use of microscopic $\mathrm{X}$-ray diffraction for the study of $\mathrm{HgS}$ and its degradation products corderoite $\left(\alpha-\mathrm{Hg}_{3} \mathrm{~S}_{2} \mathrm{Cl}_{2}\right)$, kenhsuite $\left(\gamma-\mathrm{Hg}_{3} \mathrm{~S}_{2} \mathrm{Cl}_{2}\right)$ and calomel $\left(\mathrm{Hg}_{2} \mathrm{Cl}_{2}\right)$ in historical paintings, J. of Analytical Atomic Spectrometry, vol.26(5), pp: 959-968.

[22] Parks, G. \& Nordstrom, D. (1979). Estimated free energies of formation, water solubilities, and stability fields for schuetteite $\left(\mathrm{Hg}_{3} \mathrm{O}_{2} \mathrm{SO}_{4}\right)$ and corderoite $\left(\mathrm{Hg}_{3} \mathrm{~S}_{2} \mathrm{Cl}_{2}\right)$ at $298 \mathrm{~K}$, in: Jenne, E. (ed.) Chemical Modeling in Aqueous Systems, Speciation, Sorption, Solubility, and Kinetics, Vol. 93, pp: 339-352.

[23] Istudor, I., Dina, A., \& Rosu, G., Seclaman, D. \& Niculescu, G. (2007). An alteration phenomenon of cinnabar red pigment in the mural paintings from Sucevita, e-Conservation, No. (2), pp: S 24-33.

[24] Esbrí, J., Bernaus, A., Avila, M., Kocman, D., García-Noguero, E. M., Guerrero, B. \& Higueras, P., (2010). XANES speciation of mercury in three mining districts-Almadén, Asturias (Spain), Idria (Slovenia), J. of Synchrotron Radiation, Vol. 17 (2), pp: 179-186.
[25] Da Pieve, F., Hogan, C., Lamoen, D., Verbeeck, J., Vanmeert, F., Radepont, M., Cotte, M., Janssens, K., Gonze, X. \& \& Van Tendeloo, G. (2013). Casting light on the darkening of colors in historical paintings, Physical Review Letters, Vol. 111 (20), pp: 208302 1-5.

[26] Feller, R., (1967). Studies on the darkening of Vermilion by light, Report and Studies in the History of Art, Vol.1, pp: 99-111.

[27] Davidson, R., \& Willsher, Ch. (1981). The light-induced blackening of red mercury (II) sulphide, J. of the Chemical Society, (3), pp: 833-835.

[28] Derrick, M., Stulik, D. \& Landry, J., (2000). Infrared spectroscopy in conservation science, Getty Pub., Los Anglose, USA.

[29] Vandenabeele, P., Lambert, K., Matthys, S., Schudel, W., Bergmans, A. \& Moens, L., (2005). In situ analysis of mediaeval wall paintings: A challenge for mobile Raman spectroscopy, Analytical and Bioanalytical Chemistry, vol. 383 (4), pp: 707-712.

[30] Bernaus, A., Gaona, X. \& Valiente, M. (2005). Characterization of Almadén mercury mine environment by XAS techniques, J. of Environmental Monitoring, Vol. 7 (8), pp: 771-777. 